\title{
Shifts in botanical composition of flatwoods range following fertilization
}

\author{
ROB KALMBACHER AND FRANK MARTIN
}

Authors are professars, Range Cattle Station, Ona, Fla. 33865 and University of Florida, Gainesville, Fla. 32611.

\begin{abstract}
Three annual applications of a factorial combination of $\mathbf{N}(0$, $\left.40,80,120 \mathrm{~kg} \mathrm{ha}^{-1}\right), \mathrm{P}\left(0,25 \mathrm{~kg} \mathrm{ha}^{-1}\right)$ and $\mathrm{K}\left(0,100 \mathrm{~kg} \mathrm{ha}^{-1}\right)$ were applied to Florida flatwoods range where 45 plant species were initially present. Addition of $P$ and $K$ had no effect $(P>0.05)$ on indices of plant diversity, density, or above-ground biomass. Both Shannon's $\left(Y=1.6-0.005 \mathrm{~N}\right.$, where $N$ is $\left.\mathrm{kg} \mathrm{ha}^{-1}\right)$ and Simpson's index $(Y=0.28+0.002 N)$ indicated diversity decreased with increasing $N$ because the community was being dominated by goldenrods (Solidago fistulosa and Euthamia minor) and dogfennel (Eupatorium spp.). Density of all forbs increased with increasing $N\left(1990\right.$ plants $\mathrm{m}^{-2}=17.4+0.4 \mathrm{~N}$ and 1991 plants $\left.\mathrm{m}^{-2}=35.1+1.4 \mathrm{~N}\right)$. Density of beaked panicum (Panicum rhizomatum) increased quadratically with increasing $\mathrm{N}$, while density of decumbent carpetgrasses (Axonopus spp.) and low panicums (Dichanthelium spp.) declined linearly. Broomsedge (Andropogon virginicus), wiregrass (Aristida stricta), and bottlebrush 3-awn (A. spiciformis) were eliminated from the site. Above-ground biomass of forbs increased with $\mathrm{N}(1988 \mathrm{~kg}$ $\mathrm{ha}^{-1}=934+16.1 \mathrm{~N}$ and $\left.1990 \mathrm{~kg} \mathrm{ha}^{-1}=227+60.6 \mathrm{~N}\right)$. Grass and grasslike biomass increased linearly as $\mathbf{N}$ increased, but $\mathbf{N}$ effects were independent of year, which were different $(1988=1,530 \mathrm{~kg}$ $\mathrm{ha}^{-1}$ and $1990=2,140 \mathrm{~kg} \mathrm{ha}^{-1}$ ). The plant community at this location became less diverse when the naturally low soil $\mathbf{N}$ was increased by $40 \mathrm{~kg} \mathrm{ha}^{-1}$ or more. Early successional species replaced later successional species, especially creeping bluestem (Schizachyrium scoparium).
\end{abstract}

Key Words: Florida flatwoods range, fertilization, resource allocation, plant competition, range restoration.

Fertilization has increased the quantity and nutritive value of range forage in the western U.S. (Goetz 1969, Wight 1976). In south Florida, Lewis (1970) reported an increase in above-ground biomass and nutritive value of desirable grasses growing on wiregrass (Aristida stricta Michx.) range receiving raw-rock phosphate. White (1977) reported a $250 \%$ increase in above-ground biomass of bluestems (Andropogon spp.), which are important grasses for cattle production in north Florida, as a result of $N, P$, and $\mathrm{K}$ fertilization of pine plantations. Fertilization (N,P, and $\mathrm{K}$ ) of maidencane (Panicum hemitomon Schult.), a preferred grass which forms dominant communities in fresh water marshes, resulted in greater crude protein concentration and above-ground biomass (Kalmbacher and Martin 1988).

University of Florida Joumal Series No. R-03982

Manuscript accepled 14 Jan. 1996.
Other authors have reported undesirable shifts in botanical composition as a result of fertilization (Graves and McMurphy 1969, Wilson et al. 1966). In Florida, fertilization with $N$ and $K$ initially increased above-ground biomass and tiller density of creeping bluestem [Schizachyrium scoparium (Michx.) Nash var. polycladus (Schribner \& Ball) Bruner (Syn. S. stoloniferum Nash)] in the initial year, but annual fertilization of this preferred grass resulted in lower above-ground biomass and tiller density after 3 years (Kalmbacher et al. 1993). The present paper describes plant community changes that accompanied decreases in above ground biomass and tiller density of creeping bluestem and seeks to explain why those changes occurred.

\section{Materials and Methods}

Research was conducted at the University of Florida's Range Cattle Station in south central Florida between April 1988 and September 1991 on experimental site A (Kalmbacher et al. 1993). Soil was a Pomona fine sand (sandy, siliceous, hyperthermic Ultic Haplaquod), which is representative of the nearly level, poorly drained, sandy, infertile Spodosols found in peninsular Florida. This was a treeless site which had been roller chopped for saw-palmetto [Serenoa repens (Bartr.) Small] control in 1975, and it was grazed periodically from 1977 to 1988 . The site was burned, a common management practice, in February 1988 and 1990, and was mowed in February 1989 and 1991 to remove previous year's growth and facilitate density measurements.

The experiment was a split-plot with 4 levels of $N(0,40,80$, $120 \mathrm{~kg} \mathrm{ha}^{-1}$ ) forming whole plots ( 6 by $6 \mathrm{~m}$ ), which were replicated 4 times. Whole plots were separated by a $6-\mathrm{m}$ alley to avoid lateral movement of $\mathrm{N}$. Paircd whole plots were each divided in half and these 4 sub-plots were assigned a $2^{2}$ factorial in P ( 0 or $\left.25 \mathrm{~kg} \mathrm{ha}^{-1}\right)$ and $\mathrm{K}\left(0\right.$ or $\left.100 \mathrm{~kg} \mathrm{ha}^{-1}\right)$. Ammonium nitrate, triple super phosphate, and muriate of potash were applied by hand on 15 April 1988, 2 June 1989, and 16 April 1990.

Density of all species growing in 6- by $0.166-\mathrm{m}$ quadrats was determined on 18 April 1988, 20 April 1990, and 18 April 1991. The same quadrats in each plot were examined each year. Tillers constituted the counting unit for rhizomatous plants, while an entire plant was the unit for bunchgrasses and solitary forbs. For stoloniferous carpetgrasses [Axonopus affinis Chase and $A$. furcatus (Fluegge) Hitch.], which formed 10 to 20 -cm diameter patches, the unit was a cluster of stolons. Effects on density of shrubs, forbs, grasses and grasslikes were assessed by comparing changes between samples at treatment in April 1988 with those in April 1990 and 1991, 2 and 3 years after 3 consecutive annual applications of treatments. 
Diversity indices were calculated using proportional abundance of all species at treatment in 1988 and again in 1991. These included Simpson's (Simpson 1949), Shannon's (Shannon and Weaver 1949), and Hill's numbers (Hill 1973) as cited by Ludwig and Reynolds (1988).

Above-ground biomass was measured by clipping plants at the soil surface in the permanent quadrats on 7 September 1988 and 21 September 1990, 1 and 3 growing seasons after initiation of annual treatment. Herbage was separated into shrubs (1988 only), creeping bluestem, other grasses and grasslikes, and forbs. Samples were oven-dried at $60^{\circ} \mathrm{C}$ for 96 hours and weighed. Data were analyzed using the general linear models procedure (SAS 1985) and examined as a split plot in time (years) with the repeated measures option. Significant year $\times N$ rate interactions for density were investigated using contrasts comparing the $0 \mathrm{~N}$ rate in 1988 with that in 1990 and 1991 in order to determine whether changes were due to year or treatment. Changes within year and over levels of $\mathbf{N}$ were investigated with regression analysis using observed subplot values. Calculation of $r^{2}$ is given by the ratio of regression sum of squares from the "best" fitting polynomial model to the sum of the total of the $\mathrm{N}$ rate and error sums of squares for $\mathrm{N}$. When significance is not given in the text, it implies at least $P<0.05$.

\section{Results}

\section{Rainfall}

Rainfall at the Range Cattle Station for April to September $1988(1,162 \mathrm{~mm})$ and $1991(1,336 \mathrm{~mm})$ was greater than the $52-$ year mean ( $980 \mathrm{~mm}$ ) for those months (Table 1). Rainfall in 1989 (797 $\mathrm{mm})$ and $1990(904 \mathrm{~mm})$ was less than that of the 52-year mean for this period. Extremes in rainfall and soil moisture are typical for peninsular Florida. Very dry soil is common in April and May, while soil is often covered with water or is saturated from June to September.

\section{Species Diversity}

Thirteen grasses, 21 forbs, 6 shrubs, and 5 grasslike species were encountered. Neither $P$ nor $K$ affected any measure of species diversity, but all measures of diversity were affected by $N$ rate and year, which interacted. The first of Hill's numbers, number of species (N0), averaged 10.0 species $\mathrm{m}^{-2}$ at the start in 1988 . However, $\mathrm{NO}$ in 1991 declined $(P=0.003)$ as $\mathrm{N}$ rate increased [number of species $\mathrm{m}^{-2}=11.8-0.025 \mathrm{~N}\left(\mathrm{r}^{2}=0.43\right)$, where $\mathrm{N}$ is $\mathrm{kg}$ $\left.\mathrm{ha}^{\mathrm{Al}}\right]$. Observed means were $11.5,11.5,9.3$, and 8.8 for $0,40,80$, and $120 \mathrm{~kg} \mathrm{ha}^{-1}$ of $\mathrm{N}$, respectively.

Shannon's index, which is the average degree of uncertainty in predicting the species of an individual chosen at random, was 1.2 in 1988. The index decreased $(P=0.0002)$ in 1991 as $\mathrm{N}$ rate increased (index $=1.6-0.005 \mathrm{~N}, r^{2}=0.59$ ). Observed means were $1.6,1.4,1.2$, and 1.0 for $0,40,80$, and $120 \mathrm{~kg} \mathrm{ha}^{-1}$ of $\mathrm{N}$, respectively. For comparison, Lewis et al. (1988) reported a range of 1.2 to 2.6 for Shannon's index for plant occurrence on ungrazed forested range in North Florida. Shannon's index considers both number of species and their distribution and would be zero if there was only 1 species present. It is maximum when number of species is maximum and all are equally abundant. Shannon's index decreased (diversity decreased) because number of species decreased and their proportional abundance (density is discussed below) became more dissimilar.

Hill's second number, number of abundant species (N1), is calculated from Shannon's index. It averaged 3.6 species $\mathrm{m}^{-2}$ in 1988, and in 1991, $\mathrm{N} 1$ declined as $\mathrm{N}$ rate increased $\mathrm{N1}=5.2$ $0.02 \mathrm{~N}, \mathrm{r}^{2}=0.54$ ). Observed means were $5.3,4.2,3.5$, and 2.9 for $0,40,80$, and $120 \mathrm{~kg} \mathrm{ha}^{-1}$, respectively.

Simpson's index, which is the probability that 2 species chosen at random will be the same species, depended on year and $\mathrm{N}$ rate. This index averaged 0.43 in 1988, but Simpson's index increased $(P=0.0003)$ with $\mathrm{N}$ rate in 1991 (index $=0.28+0.002 \mathrm{~N}, \mathrm{r}^{2}=0.57$ ). Observed means were $0.27,0.36,0.44$, and 0.50 for $0,40,80$, and $120 \mathrm{~kg} \mathrm{ha}^{-1}$ of $\mathrm{N}$, respectively. The probability of determining the species of an individual decreased (diversity decreased) because there were fewer species and some of those that remained were less abundant.

Hill's third number, which is the number of very abundant species (N2) calculated from Simpson's index, averaged 2.6 species $\mathrm{m}^{-2}$ in 1988, and in 1991, $\mathbf{N 2}$ decreased as $\mathrm{N}$ rate increased ( $\left.\mathbf{N 2}=3.9-0.015 \mathrm{~N}, \mathrm{r}^{2}=0.49\right)$. Observed means were $4.0,3.1,2.6$, and 2.1 for $0,40,80$, and $120 \mathrm{~kg} \mathrm{ha}^{-1}$ of $\mathrm{N}$, respectively.

\section{Density}

Shrub and grasslike densities were affected by year, but not by $\mathrm{N}, \mathrm{P}$, or $\mathrm{K}$ fertilization or their interactions. Density of all shrub species (average over all treatments) was $5.1 \mathrm{~m}^{-2}$ in $1988,2.9 \mathrm{~m}^{-2}$ in 1990 , and $3.5 \mathrm{~m}^{-2}$ in 1991 (data not shown). The most abundant shrub $\left(4.3 \mathrm{~m}^{-2}\right)$ at the beginning of the study was St. John's-wort (Hypericum tetrapetalum Lam.). Its density declined $(P=0.0001)$ to $0.42 \mathrm{~m}^{-2}$ in 1991 regardless of fertilization. Queen's delight (Stillingia sylvatica L.) increased $(P=0.0001)$ in density from 0.7 $\mathrm{m}^{-2}$ in 1988 to $2.6 \mathrm{~m}^{-2}$ in 1990 and $2.5 \mathrm{~m}^{-2}$ in 1991 . Density of queen's delight decreased $(P=0.04)$ with increasing $N$ fertilization in 1991 (no. $\mathrm{m}^{-2}=3.6-0.017 \mathrm{~N}, \mathrm{r}^{2}=0.21$ ). Density of grasslikes increased $(P=0.001)$ from $5.2 \mathrm{~m}^{-2}$ in 1988 to $7.9 \mathrm{~m}^{-2}$ in 1990 to $18.5 \mathrm{~m}^{-2}$ in 1991 . These changes were due to increases in Fuirena scirpoidea Michx. (no common name) and sedges (Cyperus spp.), which averaged 2.3 and $0.8 \mathrm{~m}^{-2}$, respectively, in

Table 1. Rainfall at the Range Cattle Station in 1988 to 1991, compared to the 52-year mean.

\begin{tabular}{llcccccc}
\hline \hline Year & April & May & June & July & Aug & Annual \\
total
\end{tabular}




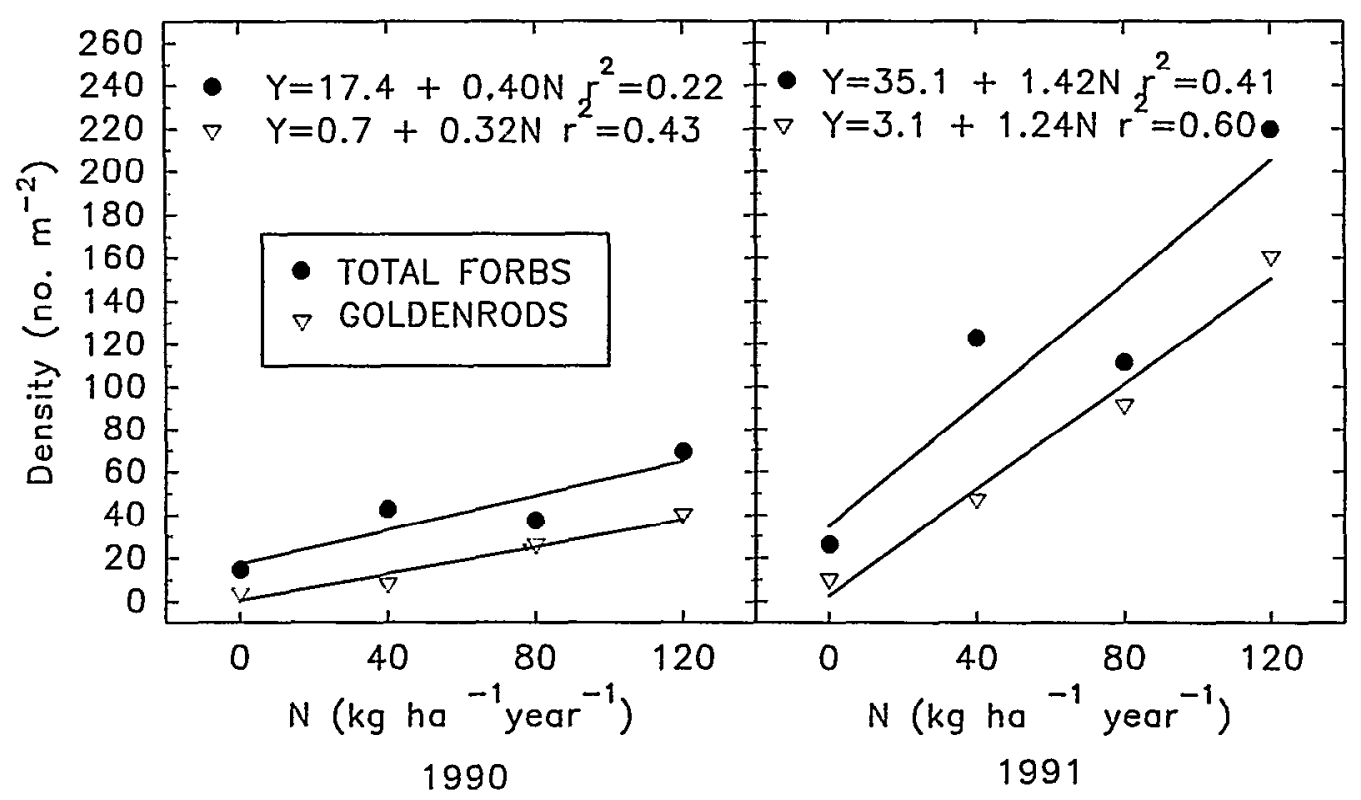

Fig. 1. Density of total forbs and 2 goldenrods, Solidago fistulosa and Euthamia minor, in April 1990 and 1991 as affected by $\mathrm{N}$ rates. Treatment means and predicted values are shown. See Table 2 for comparison of the $0 \mathrm{~N}$ rate in these years with pretreatment densities in 1988.

$1988,5.0$ and $1.6 \mathrm{~m}^{-2}$ in 1990 , respectively, and 10.9 and $4.7 \mathrm{~m}^{-2}$, respectively, in 1991.

Density of all forbs ( $31.6 \mathrm{~m}^{-2}$ ) and goldenrods (Euthamia minor [Michx.] Green and Solidago fistulosa Mill.) $\left(20.0 \mathrm{~m}^{-2}\right)$ was high at the beginning of the study in April 1988. Their density in April 1990 or 1991 was not affected by P or K fertilization, nor were there any interactions for fertilizer and year. Nitrogen increased forb density in both 1990 and 1991, but effects depended on year (year $\times \mathrm{N}$ interactions). Forb and goldenrod density did not change over years where no $\mathrm{N}$ was applied (Table 2), indicating that density was not affected by natural variation. Density increased linearly within each year when $\mathrm{N}$ was applied (Fig.1). In 1990 , each $\mathrm{kg}$ of $\mathrm{N}$ resulted in a 0.4 and 0.32 increase in forb and goldenrod density, respectively. In 1991, each $\mathrm{kg}$ of $\mathrm{N}$ resulted in a 1.42 and 1.24 increase in these respective densities, indicating that forb density was increasing with time. The proportion of the total forb density that was made up by the 2 , rhizomatous goldenrod species increased with increases in $\mathrm{N}$ rate.

Table 2. Significance levels of contrasts for density of plants in selected categories between 1988 (pretreatment) and 1990 and 1991 in control (0 N) plots.

\begin{tabular}{llc}
\hline \hline Category & Year & Probability \\
\hline All forbs & 1990 & 0.62 \\
& 1991 & 0.94 \\
Goldenrods & 1990 & 0.34 \\
& 1991 & 0.52 \\
Low panicums & 1990 & 0.01 \\
& 1991 & 0.01 \\
Carpetgrasses & 1990 & 0.05 \\
& 1991 & 0.01 \\
Beaked panicum & 1990 & 0.87 \\
& 1991 & 0.83 \\
\hline
\end{tabular}

Densities of low panicums [Dichanthelium (Hitchc. \& Chase) Gould spp.] and carpetgrasses were lower at the $0 \mathrm{~N}$ rate in 1988 (9.8 and $4.3 \mathrm{~m}^{-2}$, respectively) compared to $1990\left(31.1\right.$ and $\left.7.1 \mathrm{~m}^{-2}\right)$, indicating that density of these grasses increased naturally over years (Table 2). Density of these 2 grasses at the $0 \mathrm{~N}$ rate $(32.8$ and $8.1 \mathrm{~m}^{-2}$, respectively) was not different between in 1990 compared to 1991. Densities decreased linearly as $\mathrm{N}$ rate increased in each year (Fig. 2).

Beaked panicum (Panicum rhizomatum Hitchc. \& Chase) density remained the same over years without $\mathrm{N}$ (Table 2), but increased quadratically with increasing $N$ rate (Fig. 2). Beaked panicum formed a patchy but dense sod in fertilized plots.

Bahiagrass (Paspalum notatum Fluegge) was found in 1988 in some plots where it had been introduced through cattle feces. Average density was 0.5 tillers $\mathrm{m}^{-2}$ in 1988 , and increased to 10.3 $\mathrm{m}^{-2}$ in 1991. No treatment effects could be determined because bahiagrass was not found in enough plots for a statistical test. Common bermudagrass (Cynodon dactylon L.) was not present in 1988 , but in 1991 it was found in some quadrats receiving $N$, where its average density was $0.6 \mathrm{~m}^{-2}$.

Other grasses, like wiregrass, bottlebrush 3-awn (Aristida spiciformis Ell.), broomsedge bluestem (Andropogon virginicus L.), and maidencane were eliminated from plots. None had a density greater than 0.3 plants $\mathrm{m}^{-2}$ in 1988 , so they were minor components of the community initially.

\footnotetext{
Above-ground Biomass

Shrub biomass in September 1988 averaged $160 \mathrm{~kg} \mathrm{ha}^{-1}$, and was not affected by $N, P$, or $K$ fertilizer. Although some shrub species were relatively abundant, all shrubs were very small because of roller chopping, burning, and mowing.

Forb biomass was not affected by $P$ nor $K$ fertilizer, and there were no $\mathrm{P}$ or $\mathrm{K}$ interactions with $\mathrm{N}$ or years. Forb biomass increased linearly over $N$ rates in 1988 and 1990 (Fig. 3), which reflects increases in density (Fig. 2). Each $\mathrm{kg}$ of $\mathrm{N}$ resulted in
} 


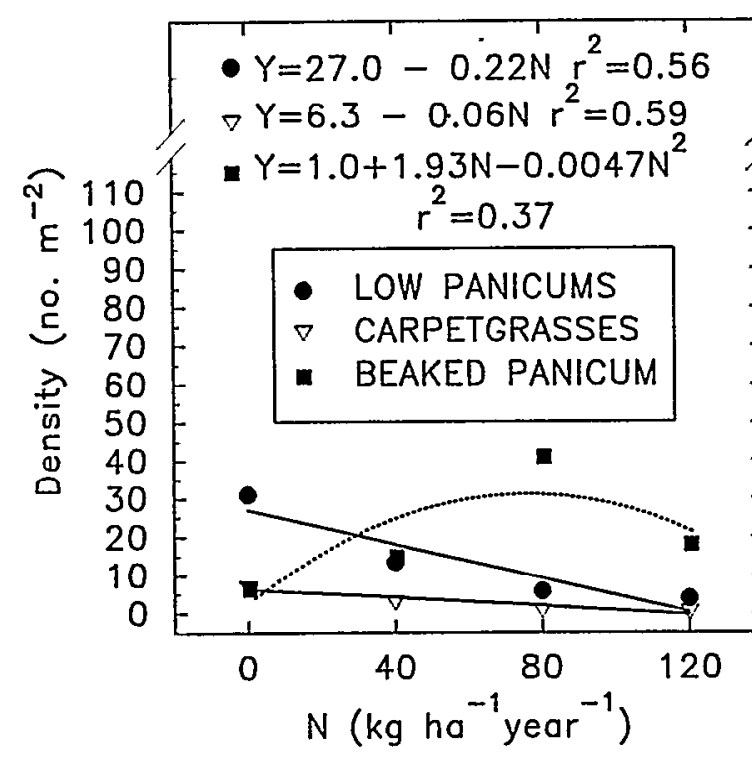

1990

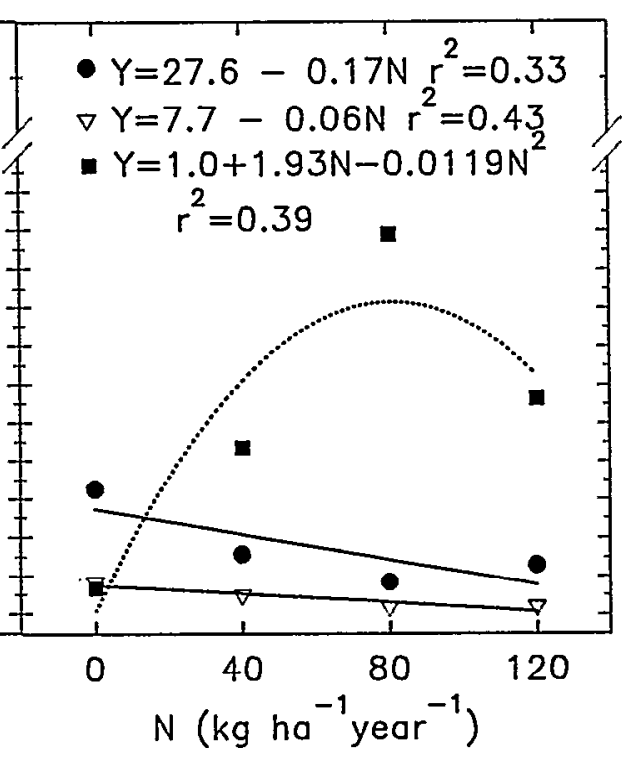

1991

Fig. 2. Density of low panicums, carpetgrasses, and beaked panicum in April 1990 and 1991 as affected by N rates. Treatment means and predicted values are shown. See Table 2 for comparison of the $0 \mathrm{~N}$ rate in these years with pretreatment densities in 1988.

$16.1 \mathrm{~kg}$ of additional forb biomass in 1988, but this increased to $60.6 \mathrm{~kg}$ of forb biomass in 1990. Both forb density and biomass increased with time. Goldenrods and dogfennels (Eupatorium spp.) contributed most to forb biomass.

Neither $\mathrm{P}$ nor $\mathrm{K}$ affected biomass of other grasses and grasslikes, and there were no interactions. Above-ground biomass of other grasses and grasslikes was affected by $N(P=0.004)$ and year $(P=0.0001)$, which did not strongly interact $(P=0.065)$. Their biomass increased linearly with increasing $N$ rate in both years (Fig. 3). Unlike forbs, whose density (Table 2, Fig. 1) and yield (Fig. 3) did not change without $\mathrm{N}$ fertilizer, above-ground biomass of other grasses and grasslikes increased in the absence of fertilization from 1988 to 1990 . This is supported by increases in density between 1988 and 1990 for low panicums and carpetgrasses (Table 2, Fig. 2) and grasslikes, as was discussed earlier.

Total above ground biomass, which includes creeping bluestem in order to provide perspective to the entire community, was affected by year and $\mathrm{N}$ rate, and there was no interaction. Total biomass averaged $6980 \mathrm{~kg} \mathrm{ha}^{-1}$ in 1988 and $7810 \mathrm{~kg} \mathrm{ha}^{-1}$ in 1990. Averaged over years, total biomass increased linearly over $\mathrm{N}$ rates (Fig. 3). Creeping bluestem biomass in September 1988 increased with $\mathrm{N}$ rate $\left(\mathrm{kg} \mathrm{ha}^{-1}=1151+39.85 \mathrm{~N}\right)$ to a maximum biomass at $5900 \mathrm{~kg} \mathrm{ha}^{-1}$ with $120 \mathrm{~kg} \mathrm{ha}^{-1}$ of $\mathrm{N}$ (Kalmbacher et al. 1993). Most of the total biomass in 1988 was creeping bluestem, but by 1990 , biomass of creeping bluestem declined quadratically with increasing $\mathrm{N}$ rate $\left(\mathrm{kg} \mathrm{ha}^{-1}=520+16.4 \mathrm{~N}-0.14 \mathrm{~N}^{2}\right)$ with maximum at $950 \mathrm{~kg} \mathrm{ha}^{-1}$ with $40 \mathrm{~kg} \mathrm{ha}^{-1}$ of $\mathrm{N}$. Forbs (especially goldenrods and dogfennels) and other grasses replaced the once dominant creeping bluestem at $\mathrm{N}$ rates above $40 \mathrm{~kg} \mathrm{ha}^{-1}$.

\section{Discussion}

The decline of diversity with increasing $\mathbf{N}$ indicates that, although the number of species found on the study area remained about the same over 3 years of treatment, the relative distribution of species changed as forbs and beaked panicum became more abundant and creeping bluestem became less abundant as $\mathrm{N}$ rate increased. Range scientists have not focused on species diversity in the past, but instead have usually reported positive or negative effects on a few plants that were important for livestock production. Community ecologists studying the entire plant community have reported reductions in species diversity as a result of $\mathrm{N}$ fertilization of nutrient poor sites (Huenneke et al. 1990, Parish et al. 1990, Wilson and Shay 1990, and Wilson and Tilman 1991).

Creeping bluestem had been a dominant grass on this nutrient poor site. Creeping bluestem is a strongly thizomatous ecotype of the bunchgrass, little bluestem [Schizachyrium scoparium (Michx.) Nash-Gould], and it may differ from little bluestem in response to ecosystem fertility. Little bluestem is a strong competitor for $\mathrm{N}$ on an infertile soil (Tilman 1989) due to lower vegetative growth rates, higher root allocation, lower reproductive allocation and lower tissue $\mathrm{N}$ than other grasses classified as early successional species (Tilman and Wedin 1991).

Goldenrods, dogfennel, and beaked panicum became more abundant and dominant on our Florida site when $\mathrm{N}$ was applied. We believe that the forbs and beaked panicum represent early successional species. Old-field herbs that represent early successional species were inferior users of $\mathrm{N}$ when it was limiting, had higher maximal growth rates, and were better colonizers than later successional species, such as little bluestem (Tilman and Cowan 1989).

Early successional species are part of the current flora of the Florida flatwoods range and may become dominant with additions of $\mathrm{N}$ into the system. Dogfennel (Eupatorium compositifolium Walt.) and goldenrod (Solidago microcephella [Greene] Bush), originally present in small amounts, became dominant forbs under moderate fertilization on Georgia range (Halls et al. 1957). 


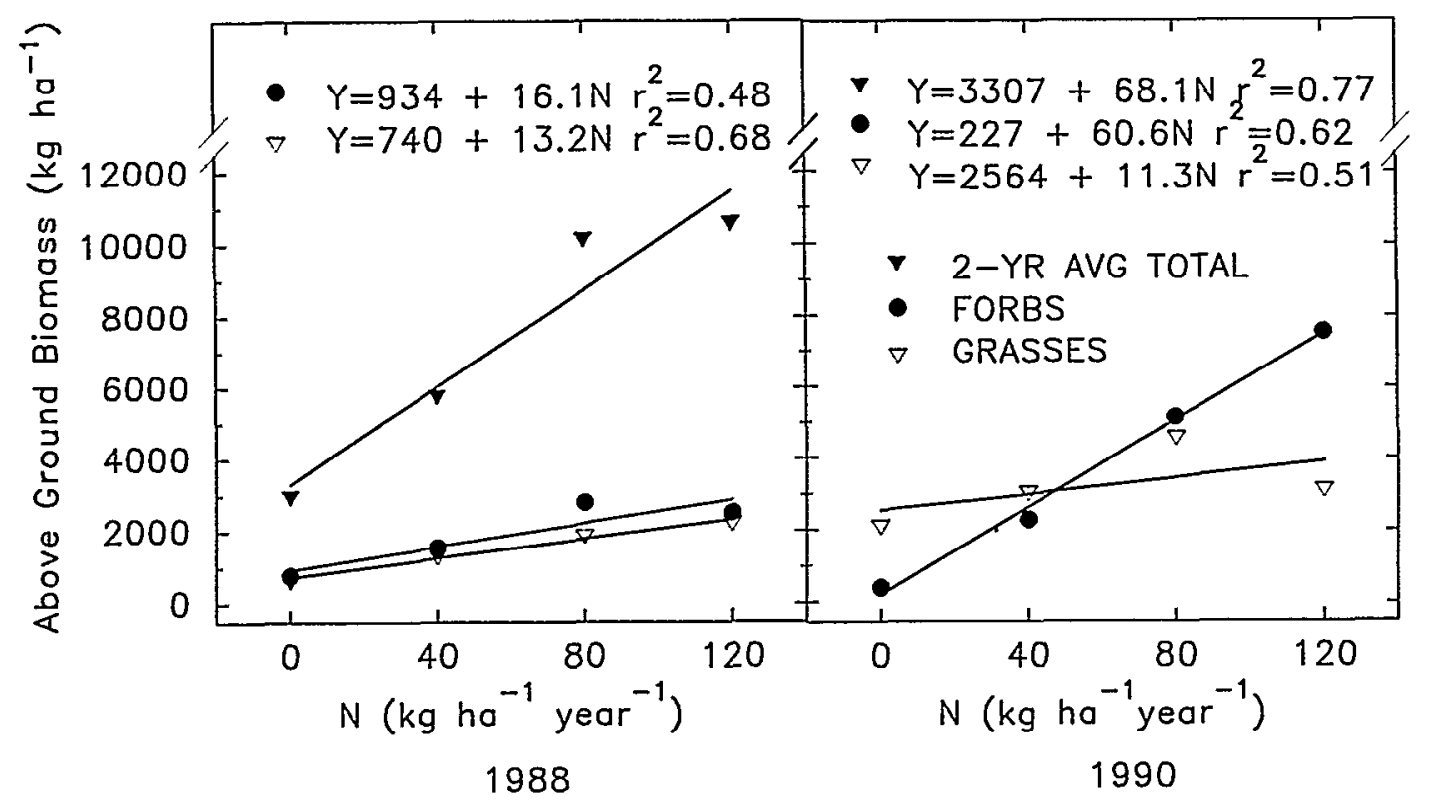

Fig. 3. Effect of $\mathbf{N}$ rate on above-ground biomass (dry matter) of total forbs and grasses and grasslikes (excluding creeping bluestem) in September 1988 and 1990 compared with total above-ground biomass (including creeping bluestem) averaged over 1988 and 1990. Treatment means and predicted values are shown.

The fact that the early successional species on our range were rhizomatous may have implications, although no support for this was found in the literature. Early successional species with a rhizomatous habit of growth may be more rapid colonizers because they combine an ability to rapidly acquire $\mathrm{N}$ when it is abundant and use their greater maximum growth rate for vegetative reproduction.

Light penetration to the soil surface decreased with fertilization (Wilson and Tilman 1991, 1993). Reduction in light by forbs may have little effect on taller grasses like creeping bluestem, but would limit growth of small forbs and decumbent grasses such as carpetgrasses, low panicums, or even bottlebrush 3-awn, which is a small bunchgrass.

We cannot recommend any addition of $\mathrm{N}$ or other fertilizer elements to south Florida rangelands in an effort to improve aboveground biomass. The desirable grasses for livestock production are later successional species and are better able to compete on sites where soil $\mathrm{N}$ is found in low concentrations.

\section{Literature Cited}

Goetz, H. 1969. Composition and yields of native grassland sites fertilized at different rates of nitrogen. J. Range Manage. 22:384-390.

Graves, J.E. and W.E. McMurphy. 1969. Burning and fertilization for range improvement in central Oklahoma. J. Range Manage. 22:165-168.

Halls, L.K., G.W. Burton, and B.L. Southwell. 1957. Some results of seeding and fertilization to improve southern forest range. USDA Forest Serv. Res. Pap. No. 78. Asheville, N.C.

Hill, M.O. 1973. Diversity and evenness: a unifying notion and its consequences. Ecol. 54:427-432.

Huenneke, L.F., S.P. Hamburg, R. Koide, H.A. Mooney, and P.M. Vitousek. 1990. Effects of soil resources on plant invasion and community structure in a Californian serpentine grassland. Ecol. 71:478-491.

Kalmbacher, R.S. and F. G. Martin. 1988. Effect of defoliation frequency and N-P-K fertilization on maidencane. J. Range Manage. 41:235-238.
Kalmbacher, R.S., F. G. Martin, and J.E. Rechcigl. 1993. Effect of N-P$\mathrm{K}$ fertilization on yield and tiller density of creeping bluestem. J. Range Manage. 46:452-457.

Lewis, C.E. 1970. Responses to chopping and rock phosphate on south Florida ranges. J. Range Manage. 23:276-282.

Lewis, C.E., B.F. Swindel, and G.W. Tanner. 1988. Species diversity and diversity profiles: concept, measurement, and application to timber and range management. J. Range Manage. 41:466-469.

Ludwig, J.A. and J.F. Reynolds. 1988. Statistical ecology: a primer on methods and computing. John Wiley \& Sons, N.Y..

Parish, R., R. Turkington, and E. Klein. 1990. The influence of mowing, fertilization, and plant removal on the botanical composition of an artificial sward. Can. J. Bot. 68:1080-1085.

SAS Institute, Inc. 1985. SAS users guide: statistics. Version 5 Edition. Cary, N.C.

Shannon, C. E. and W. Weaver. 1949. The mathematical theory of communication. Univ. Illinois Press. Urbana, Ill.

Simpson, E.H. 1949. Measurement of diversity. Nature 163:688.

Tilman, D. 1989. Competition, nutrient reduction and the competitive neighbourhood of a bunchgrass. Funct. Ecol. 3:215-219.

Tilman, D. and M.L. Cowan. 1989. Growth of old field herbs on a nitrogen gradient. Funct. Ecol. 3:425-438.

Tilman, D. and D. Wedin. 1991. Plant traits and resource reduction for five grasses growing on a nitrogen gradient. Ecology 72:685-700.

White, L.D. 1977. Forage production in a five-year-old fertilized slash pine plantation. J. Range Manage. 30:131-34.

Wight, J.R. 1976. Range fertilization in the northern Great Plains. J. Range Manage. 29:180-185.

Wilson, A.M., G.A. Harris, and D.H. Gates. 1966. Fertilization of mixed cheatgrass-bluebunch wheatgrass stands. J. Range Manage. 19:134-37.

Wilson, S.D. and J.M. Shay. 1990. Competition, fire, and nutrients in a mixed-grass prairie. Ecol. 71:1959-1967.

Wilson, S.D. and D. Tilman. 1991. Interactive effects of fertilization and disturbance on community structure and resource availability in an oldfield plant community. Oecologia 88:61-71.

Wilson, S.D. and D. Tilman. 1993. Plant competition and resource availability in response to disturbance and fertilization. Ecol. 74:599-611. 